\title{
GENERAL CHARACTERISTICS OF THE BASIC CONCEPT OF TERRORISM $^{* *}$
}

\begin{abstract}
Scientists trying to reach a consensus on the meaning of the term "terrorism" and how to deal with it have concluded that it is almost impossible to find a framework for a single generally accepted definition. When considering the conceptual determination of the word "terrorism", fragmented attitudes should serve as a warning that we are walking on thin ice where there is a collision of numerous definitions, a wealth of determinations with numerous discrepancies, contradictions, inaccuracies, and ambiguities. Some of the definitions are short and precise, and some implicitly explain what 'terrorism' means, some concepts coincide with those on which the content of the notion of terrorism is based, whereas some formulations are based on the delimitation of this criminal act in the field of national legislation. Ultimately, to summarize, at no point in history has this complex theme been discussed as it is today, while the results have been modest, even unsatisfactory. In short, progress in that sense has not been made. However, individual and collective scientific thought has contributed to defining the legal outlines of terrorism. Finally, its features have been determined significantly by international contracts and case law, which have clarified this concept, its main features. Based on this reference, as the author points out, significant differences exist between the aforementioned theoretical positions. The author says that a look at the level of substantial delimitation of concept terrorism will enable us to obtain interesting and applicable conclusions, which can be further used in explaining and scrutinizing both the characteristics and the specific content of the notion of terrorism, all in the function of looking for the most suitable model to fight against it.
\end{abstract}

Keywords: concept of terror, definition of terrorism, distinction between terrorist and freedom fighter.

\footnotetext{
* PhD, Research Fellow, Institute of Comparative Law, Belgrade, Serbia, e-mail: d.petrovic@iup.rs

${ }^{* *}$ This paper was written as a part of the Research Programme of the Institute of Comparative Law for 2020, which is supported by the Serbian Ministry of Education, Science and Technological Development.
} 


\section{Introduction}

The introductory definition of the phenomenon that will be discussed should enable us to see the reason and meaning of a certain phenomenon, to understand its essence. However, if it is not possible to define it precisely, then a path must be charted that leads to its boarder definition. In terms of concrete analysis, the fundamental and initial analytical category includes the reasonable meaning of the term "terrorism", where its numerous and various aspects are considered separately: motivation, geographical contexts, aspects of terrorist association or their individual operation; future forms of terrorist engagement; certainly, various ethical issues and problems play an important role, with particular attention being drawn to the illuminating of the of image of terrorism which is being created by the media.

The concepts of terror and terrorism are still vague and greatly misused. Simultaneously, their connection to other forms of violence and crime is often and quite noticeably ambiguous. It is just that intricate web of subjective factors and reactions to the topic of terror and terrorism that makes these concepts significantly more complicated to define.

Precisely those who endeavored to reach a consensus related to the meaning of the word "terrorism" and how to tackle its problem concluded that it is nearly impossible to find a frame for a simple and generally accepted definition (Smidt, 2004). All of us use this term, however, no one can explain it adequately, despite numerous attempts which are mostly directed at and limited to highlighting intentional causes and dreadful consequences.

However, although a consensus in defining terrorism does not exist, there is a generally accepted understanding that terrorists today operate globally and that their activities have become more frequent. In the last couple of years, this tendency has shown its true face by bringing about extreme chaos and violence.

The peculiarity of the problem is reflected, among other things, in the fact that the concern regarding the scope of terrorist activities is more than ever focused on the possibility that the terrorists might acquire chemical, biological, or even nuclear weapons of a smaller range. The world is facing an immense risk "in its own yard", and terrorism is already "at our doorstep".

Why is it so difficult to define terrorism?

There are a few words that have imposed themselves on our day-to-day vocabulary like this one. Like the word "Internet", so has the word "terrorism" found its way into wide usage, without us understanding its real meaning. These inaccuracies have also arisen as a consequence of the imprecise usage of the word in the media, which attempt to convey a complex message in a limited time or space, by simply labeling the most varying forms of violence as terrorism (e.g. bombing a building, assassination of the president, massacre of the population by a military unit, poisoning the population with a certain product from the supermarket or intentionally contaminating medicine in a pharmaceutic unit, etc. are all called the same - terrorism).

Today, the meaning of the word terrorism is of a fundamental political nature (Stuurman, 2019, pp. 1-2; Jazić \& Batrićević, 2016). It is inseparable from the word 
"power" - seeking to attain power, acquiring power, the usage of force etc. All of this is used to achieve political goals. Terrorism is also violence or the threat of violence, which is used in direct service for a political goal or towards achieving a political goal. When this essential part is explained and clarified, only then do we understand another definition of "terrorist" given by US Department of Defense (DoD): a terrorist is anyone who tries to impose their views through a system of coercive intimidation (Smidt, 2004). This definition underlines a few more of the fundamental characteristics of terrorism - that it is a planned, calculated, and systematic act.

\section{Approaching the Problem}

The problem of defining terrorism has plagued the international community for years. The UN General Assembly has scheduled international conferences on several occasions, precisely intending to resolve this problem (Duchemann, 2013, p. 179). ${ }^{1}$ Unfortunately, the general definition of terrorism was difficult to reach. Today, certain efforts are re-emerging to reach an international consensus on the definition of terrorism, and which would derive from existing definitions of war crimes "as a detour, across swamps and ponds" (Jenkins, 1981, pp. 3-10; Petrović, 2007, pp. 44-59).

Terrorism is manifested by a series of various criminal activities calculated to lead to human casualties or damage to property or other goods and interests. But definitions can become standards if each circumstance is analyzed individually, providing a broader framework for understanding the definition only in terms of ultimate goals, and do not define it from the aspect of ideology or the way in which terrorist actions are carried out.

In that context, any more detailed presentation of the general concept of terrorism would be superfluous, because this reference is enough to show how the permeation of political power and authority through the various motivations of their actors is expressed in a kind of diversity of terrorist acts. A multitude of acts that are labeled or can be classified under the term terrorism, with the irrevocable accuracy of warning of the unique conclusion that, above all, the basic reason for a comprehensive and generally accepted definition of terrorism should be sought here.

From this general position, all formulations determined by different criteria have a lot in common (they had a basic core). Also, there are quite a few different points of view. ${ }^{2}$

On this list of numerous and diverse definitions, there are differences in emphasizing different things. Some definitions (referring to the official ones) reflect institutional positions. For example, the FBI emphasizes illegality, as well as, the undertaking of property crimes to

\footnotetext{
${ }^{1}$ In European Union terrorism is defined by the Framework Decision of 13 June 2002. See Matić Bošković, 2016, pp. 106-108.

${ }^{2}$ It is difficult for the United Nations to reach a minimum of consensus in defining terrorism. Some (smaller) member states of the United Nations somehow narrow the usual meaning of terrorism by excluding various variants of armed struggle believing that national liberation and resistance movements against foreign occupation should not be labelled "terrorism". Others, in defining terrorism insist on such a concept implying "the means by which the fight is waged" but not the goal. In the absence of consensus, the United Nations has opted for such a theoretical position that reflects a medium approach to interpreting that particular phenomenon (Arlacchi, 2001; Scharf, 2001, p. 135).
} 
achieve social and political goals, while the State Department emphasizes that actions are pre-planned (Stuurman, 2019). The potential political motivation of para-national groups is also mentioned. Spontaneous violence is not mentioned, nor are psychological moments of threats considered. In that sense, the US Department of Defense acts more comprehensively and attaches equal importance to real and threatening violence, gives a wider range of targets by classifying not only governments but also entire societies as possible targets. ${ }^{3}$

In the United Kingdom definition of terrorism is given in a law of 2000. There is a controversy that this definition is too broad and could lead to the government restricting or even rejecting the legitimate rights of a large number of groups to protest (Duchemann, 2013). Several authors emphasize an intimidation strategy that instills and incites fear and feelings of personal vulnerability among the civilian population (psychiatrist Reich), while some authors focus on the use of intentional intimidation, citing attitudes and behaviors as examples (Sederberg), and finally, some definitions are full of emotional charge and condemning resentment (Walker, 2002, pp. 20-21).

At this point, it is important to note that there are a number of different problems that block efforts to "finally define" terrorism. ${ }^{4}$ First, there is an understandable but confusing tendency to confuse explanations, justifications, and reprimands with many definitions. Second, the confusion between action (terrorism), actor (terrorist), and effect (terror) negatively affects our ability to distinguish between terrorism and the higher class of violent behavior of which it is a part (Stuurman, 2019). Finally, the option to focus on different subtypes of terrorism (e.g., air piracy, suicide bombings ${ }^{5}$ ) does not explain what it is in these subtypes that motivates individuals to become terrorists. Although we could formulate a certain policy for responding to certain terrorist activities, we would be forced to stop looking for a greater general understanding and strategy (Whittaker, 2003, pp. 4-5).

\section{Necessary general framework}

Starting only from the external definition, therefore ignoring the nuanced differences here in the precise limitation of the meaning of the term "terrorism", a high degree of agreement was shown in the following.

Terrorism is a strategy of violence designed to achieve the desired results by spreading fear and insecurity:

\footnotetext{
${ }^{3}$ Institutional definitions emphasize the illegal use of force and committing crimes against property, goods and infrastructure. In 2001, the US government made every effort to express its disgust towards those who dared to attack the centuries-old symbols of democracy and state order in front of their doors. Academics, psychologists, criminologists and journalists are especially careful when emphasizing in their definitions the reasons why political activism has become violent, as well as the fact that terrorist threats have made the public very vulnerable (Whittaker, 2003, pp. 4-5; Stuurman, 2019).

${ }^{4}$ Since then, scholars, organizations, and government agencies across the world have created more than 260 definitions of "terrorism", which have been chronicled by Schmid, a research fellow at the think tank the International Centre for Counter-Terrorism. And debates continue about whether some historical figures, such as Gavrilo Princip who in 1914 assassinated Archduke Franz Ferdinand and his wife in Sarajevo leading up to World War I, are terrorists, heroes or something else entirely (Schmid in an interview: Kelkar, 2017).

${ }^{5}$ See more in: Petrović, 2009.
} 
- this is the illegal use of force or threat of force, through a continuous campaign or sporadic incidents;

- this is a deliberate use of violence against civilians and non-military targets;

- here the power and force are inextricably rooted in political violence - from their acquisition through manipulation to using them to achieve the effect of change;

- revolutionary terrorism: aims to bring about complete changes in the state;

- sub-revolutionary strategies aim to lead to political changes, without leading to the collapse of the political system;

- in a word, these are carefully planned covert activities related to the goals, means, targets of attacks, and accession of participants (Petrović, 2014);

- goals can be political, social, ideological, or religious - without them terrorists would be considered ordinary delinquents and criminals (Wilkinson, 2004, p. 192);

- terrorist actions are usually carried out by sub-national groups, and sometimes by lone individuals committed to a goal;

- an important goal of these actions is to achieve maximum publicity;

- zones of activity include a specific country, a specific location, or a special segment of society; they quickly acquire a transnational character because the echoes of the action transcend the borders of a country (Petrović, 2007, pp. 34-45).

A cursory reading of the above list shows the reasons for the general disapproval of terrorism and the readiness to condemn such an uncontrolled and unrestrained, ruthlessly destructive phenomenon of the modern world. In fact, this brings us back to the beginning: it is as if the understanding of terrorism revolves in a vicious circle, which is why we must once again resignedly state that under various definitions of terrorism, warns only of its necessary general framework. Hence, we will only indicate the theoretical issue of "content and dynamics" which we will deal with in the next part of the text, which is dedicated to these segments in explaining the marked topics.

The definition of terrorism is extremely vague due to political disagreements. On the other hand, the law is by its very nature obliged to provide an authoritative determination of criminal activities. However, there is always a danger that politically motivated linguistic opportunism will produce simple labeling of this term. ${ }^{6}$

It seems that terrorism, as a derivation of the word terror, has acquired the meaning it deserves. However, much also depends on the aspect in which it is used. Differences in views can be expected between the authorities responsible for order and peace, observers who have witnessed these activities directly (Stuurman, 2019) "first-hand" or through the media, as well as the victims of terrorists themselves. All of them are specifically identified with terrorism (Baudrillard, 2003, p. 141).

\footnotetext{
${ }^{6}$ In its narrower and specific meaning, terrorism is "considered a pejorative expression, so that the names of action and reaction underline determinants such as freedom, defence, liberation, the army and just revenge" (Pinjo, 2015). Noting that new definitions, arguments, and counter-arguments are constantly being presented about terror and terrorism, the impression was created that all (regardless of the differences determined by socio-political and religious-cultural approaches to the problem) and small groups, entire people's movements and state regimes use terrorism to a greater or lesser extent as an instrument of "just struggle." See more about it: Pinjo, 2015.
} 
Authorities must tackle behaviors they believe go beyond ordinary protests and demonstrations. Therefore, the state reacts quickly to remove the threat to order, peace, and security. This approach, which does not allow "unreasonable activities", leaves little room to consider the true, internal causes.

Naturally, the observers do not approve of deadly, malicious and anti-social forms of behavior. However, often among conservative media, any more violent form of behavior is characterized as malicious, so the term terrorism is often used to describe the whole range of protests such as hooliganism among fans, street riots or the appearance of people in a drunken state.

The victims, regardless of whether targeted or accidental, innocent bystanders consider the violence by which they are victimized as a dramatic end because it endangers their health, mobility, even life. When political violence restricts the freedom of movement of people (as in the case of the Palestinians and Israelis, for example), then terrorist operations are an exclusive factor that violates basic human rights, and large number of people are unhappy in the true sense of the word.

Terrorists are called destructive maniacs, people with a distorted mind and irresponsible violators of all codes of civilized behavior. While the public is more inclined to deal with the consequences rather than the causes of terrorist activities, especially when in a state of shock, those who have resorted to political violence do not accept to be labeled as terrorists and try to prove they had no choice but to react. They would draw attention to their idealistic, sometimes even altruistic goals (Stuurman, 2019).

Therefore, it is clear that the meaning of the terms terrorism and terrorists are largely determined by the point of view of those who define them. Numerous prejudices cannot be ruled out either (Schmid, 2004, pp. 377-378). After all, perhaps this is illustrated the best by the view of professor Richard Falk, who expressed it in an interview (1997) with the words that terrorists are often viewed in a simplified way through the prism of self-respect and moral-legal principles emphasizing the positive values of the western system which threatens unbridled political violence.

Thus, problems in determining the meaning and essence of terrorism remain. Faced with the lack of a generally accepted, universal definition, any state can sign a declaration against terrorism without having to fully implement its commitments in practice. States that have signed the Convention on the Suppression of Terrorism often define terrorism in different ways (principle of "double standards") (Duchemann, 2013). For example, terrorist activity within its state borders is rigorously punished, while violent political activities that take place in the territories of some other states are not considered fanatical or are even ignored. On the other hand, it is necessary to provide a minimum of basic agreement (at least give coordinates) on a framework definition that defines terrorist activities as the intentional use of violence outside the battlefield, aimed at the civilians to achieve a particular political goal. Brutal attacks of this kind would be considered a barbaric, unacceptable form of behavior. They would have nothing to do with conventional warfare between conflicting military forces whose characteristics, principles and limitations are strictly defined by the Geneva and Hague Conventions. They should also differ from the 
guerrilla mode of warfare, which is significantly different from terrorism, because the targets are military, not civilian.

Of course, in theory and practice, the prevailing opinion is that in order to better understand this phenomenon, it is necessary to expand the context in which it is observed and researched, i.e. interpreted and explained.

Different words and attitudes interfere with the meaning of the word terrorism, especially when there are difficulties in trying to expose terrorists and guerrillas and freedom fighters. There are differences between these three notions in terms of their use of violence:

- the targets of terrorists are civilians,

- guerrillas attack soldiers and military officials and facilities,

- freedom fighter campaigns in order to free his people from dictatorial directing or occupying power.

Providing a broader framework for understanding, another problem has arisen in explaining this topic. Namely, terrorism traditionally means a "two-way fight" between a group of terrorists, on the one hand, and a sovereign state on the other. However, in the modern world, attention is drawn to countries that use terrorist organizations to promote their interests internationally.

Here, it should be emphasized once again that the lack of consensus on the definition of terrorism at the international level significantly hinders the effective fight against terrorism. More precisely, international cooperation aimed at preventing states from "sponsoring terrorism" is weak. In many cases, governments that fund terrorist actions are authoritarian, and their people are not interested in opposing them or even supporting them (as is the case in most Muslim countries) (Baer, 2003, p. 98).

Can countries that fund this horrific phenomenon do anything more, significantly differently, to divert their "clients" from persevering in actions that the rest of the world finds disgusting and unforgivable? There are certain indicators of how this process is already happening.?

\section{Special answers common to the general notion of terrorism}

1. When considering the issue of terrorism, there are many factors that contribute to its complexity, including the emotional nature of the issue, political disagreement around it and even the degrading connotation of the term. Although it is difficult to find a definition of terrorism that does not contain the word violence, this concept of using violence, which can be used by almost everyone and in almost all conflict situations, is related to certain actors and certain types of conflicts. The phrase "For one terrorist, for another patriot" is

\footnotetext{
${ }^{7}$ In many cases, the criteria used by Americans and Israelis to condemn Hezbollah or Hamas are not supported by most of the Arab world, especially in Lebanon and Syria. Palestinians believe that Israeli punitive expeditions to their cities and farms unfairly classify them as terrorist states. Many countries that sponsor terrorism in the Middle East view terrorist actions as jihad, a holy mission, and a war against the godless West. Terrorism can be defined here as a redemptive, pan-Islamic struggle.
} 
often mentioned as proof that this concept is subject to double standards. ${ }^{8}$

2. In this way, quite understandably, terrorism also appears as a problem of morality - we can say attempts to define it are precisely based on it [the morality] (Barber, 2004, p. 16; Petrović, 2007, pp. 59-63).

The assumption is that some types of political violence are morally justified, while others are not. Violence is defined in terms of coercion, the authority of legitimacy, so it is difficult for governments, politicians, and lawyers to remain impartial. One of the problems of criminal prosecution occurs in the case of terrorist acts that produced terror by threatening violence, without physical destruction, i.e. injuring of people and damage to the property. However, violence is a crucial element of terrorism, recognizable in cyberterrorism as well, although it is potentially disruptive and directed against the system rather than a physical human body (Combs, 2016, p. 6).

The UN General Assembly could not agree on a standard definition of terrorism, which must contain a universal rather than a pro-Western meaning. As Kelkar (2017) says:

\begin{abstract}
"The United Nations has spent more than 20 years trying to form a consensus on what constitutes terrorism, but has yet to succeed. Sticking points are usually about conflicting national interests and unwillingness to change national legislative traditions. Having sat in some of the meetings, Schmid noted during a presentation on terrorism at a symposium in 2014 that the political value of the term to individual nations continued to prevail over a legal definition that would make it universally punishable. He recently wrote in an email that his best short, legal definition that he proposed during the symposium was the, 'peacetime equivalent of war crimes"'.
\end{abstract}

International terrorism can be distinguished from terrorism at the national level in the presence of an element of international jurisdiction. Transnational terrorism, a term often misused as a synonym for international terrorism, ${ }^{9}$ can be considered a subgroup of qualifiers whose terrorism with a specific focus on non-state and non-political actors (Zirojević Fatić, 2014, pp. 163-166).

3. The word terrorism is often used with the terms: "often", "mostly", "generally" and "usually". These attributes make it possible to express a personal opinion when assessing whether an act is terrorist or not. Definitions of terrorism would have a significant level of objectivity if they were focused on the nature of the act and not only on the identity of the perpetrators or their targets.

This makes it possible to distinguish between transnational terrorism and terrorism of autonomous non-state actors (who may have some form of foreign support), and

\footnotetext{
${ }^{8}$ In the absence of a generally accepted international definition, certain states have decided to appear "as a community" in the fight against terrorism. Authorities (both in the East and in the West) tend to call their opponents terrorists, even when they have not used violence. Guerrillas refuse to be called terrorists by regime governments. Many government actions involving violence are considered legitimate because governments are democratically elected (Whittaker, 2003, p. 11).

${ }^{9}$ See: Petrović, 2007, pp. 232-242.
} 
international terrorism perpetrated by individuals or groups under the control of sovereign states (Milbank, 1976, p. 11).

4. Terrorism is carried out for various reasons. Individual acts of terrorism may involve making specific concessions, such as releasing an important person from prison. Terrorism can also be carried out to deliberately provoke repression which would bring a government into a position of self-destruction. In the Irish case, terrorist acts were carried out with to punish the opponents. But respect for such circumstances as the perpetrator's social, cultural or national situation disrupts the objectivity of labeling an act as a terrorist (Miller in: Kelkar, 2017).

5. Terms such as freedom fighter or liberator are attempts to downplay the seriousness of an essentially very "ugly and filthy" profession. However, there is a thin line between the terms terror and terrorism (Petrović, 2007, pp. 69-74). The terror practiced by a legitimate government is served as if it were law enforcement and is aimed at the opposition, while terrorism involves defying the law and is the opposition's means of destroying power (Milbank, 1976, pp. 11-19).

6. The definition of terrorism is further complicated if we consider the typology, i.e. the location where terrorist groups are formed and where terrorist activities are carried out. Here we distinguish three points of view: terrorism committed outside the territory of the state whose citizen is the perpetrator of the terrorist act; terrorism calculated to endanger the interests of a state by its citizens and terrorism calculated to damage, significantly disrupt relations between different states.

When defining terrorism, one concept often emerges in favor of terrorists and that is that all acts of violence (hijacking, bombings, assassinations and destruction of infrastructure, etc.), are a consequence of human nature, which is inherently aggressive and destructive (Petrović, 2014).

What happened is that terrorist campaigns achieved their goals. In some cases, terrorism has been proved to be more effective and cheaper than conventional and guerrilla warfare because its goal was not to destroy the adversary but to break his will so that he capitulated.

7. Thus, definitions of terrorism must be analyzed in the context of the following sciences: history, philosophy, psychology, sociology, politics, statistics, linguistics, and law. In considering the definition of terrorism, the basic assumption is objectivity, which implies being open to every possibility and suggestion. And only in that sense, it is necessary to stand on the positions of those theories that are aware of the limitations of language and the possibility of interpretation, but which try to create the necessary general framework, at least a relief pattern for formulating goals and programs in the fight against it.

8. While no official agreement can be reached globally on the definition of terrorism, almost all of us have a basic idea of what terrorism is. It manifests itself in different variants: repression, fraud, racism, exploitation, control of information, violation of privacy, endangerment of human freedoms, corruption, etc. The eternal question of the morality of terrorism does not focus so much on the achievement of political goals as on the release of oppressed people, the end of colonial rule, the collapse of the authoritarian regime, the release of political prisoners and similar. The conditions that accompany terrorist actions 
influence the shaping of public opinion. Lethal violence against some person in so-called democratic countries is considered less acceptable than a violent uprising of oppressed people in a colonial state (Petrović, 2015, pp. 645-660).

9. Terrorism is a calculated activity primarily aimed at creating a general atmosphere of fear to influence the political course of events. The result of terrorist actions must be terror; otherwise, they could not be characterized as terrorist actions. Terrorism can be a single act of violence. However, it is an incomplete definition that comes down only to the element of violence, the threat of violence, repressive actions, and similar. Such an approach cannot be leading to a final definition of this phenomenon. Success of a terrorist action is measured by how much it has succeeded in weakening the capacity of elected representatives of the government and causing feelings of personal insecurity, i.e. "sowing doubt in the duties and obligations of the state".

To conclude, some key generalizations in this field can be found in the literature, such as substitution for the conventional way of warfare, weapons of the weak, pathological acts of violence, the state's reaction to violence, etc. These generalizations made it even more difficult to define terrorism. Misconceptions about terrorism appear because the definitions are exclusively a 'product' of the West or third world countries. New polarizations and political relations, technological achievements, new motivations, and types of violence additionally prevent the adoption of a clear concept of terrorism, which is a condition for an effective fight against terrorism at the international level. Unfortunately, the fight against terrorism seems to have no end and the next generations should be ready so that it can never be eradicated. The age of terrorism can last for centuries.

\section{Conclusion}

Despite the rapid increase of terrorism on a global scale, the term "terrorism" still is not clearly defined nor nearly acceptable. Some governments tend to call all acts of violence committed by their political opponents as terrorism. On the contrary, anti-government extremists claim that they are the victims of state terror.

The imprecise nature of this term enables it to be used for labeling as terrorism all the activities which "bring about fear in order to achieve various goals". The term can in the broadest sense be used for describing other types of violent acts, such as kidnapping and abducting an aircraft, for which the perpetrators had not planned to grow into terror. Unfortunately, political sociologists deem that a simple and universal definition cannot be obtained, because the very process of defining the term represents a bigger part in constellating ideological and political goals. The struggles in defining the term support the argument that the perspective changes based on when and where the terrorists have committed their act. The question of defining terrorism is central for understanding this phenomenon, as well as for the success of measures taken against it. Therefore, the problems in defining the meaning and essence of terrorism remain. Confronted with a lack of a generally accepted and universal definition, each country can sign a declaration against terrorism, without having to fully perform its obligations in practice. Countries 
that have signed the International treaty against terrorism often define terrorism differently (the double standard principle). On the other hand, it is necessary to ensure a minimum basis of the agreement (at least, providing coordinates) about an approximate definition which describes terrorist activities as purposeful usage of violence outside of the battlefield, aimed at civilian populations to accomplish certain political goal. Brutal attacks of this kind would be considered a barbaric and unacceptable way of behavior. These acts would not have anything in common with the conventional way of leading a war between conflicting military forces whose features, principles, and limitations are strictly defined by the Geneva and Hague conventions. They would also have to be differentiated from guerrilla warfare, which as mentioned before is notably different from terrorism because the targets involved are military and not civilian.

\section{References}

Arlacchi, P. 2001. Opening Remarks. Countering terrorism through international cooperation: Proceedings of the international conference on "Countering terrorism through enhanced international cooperation", Courmayeur Mont Blanc, Italy, 22-24 September 2000. Milan: ISPAC.

Baudrillard, J. 2003. Duh terorizma. Zagreb: Meander.

Baer, R. 2003. Sleeping with the Devil: How Washington Sold Our Soul for Saudi Crude. New York: Crown.

Barber, B. 2004. Fear's Empire: War, Terrorism, and Democracy. New York: W.W. Norton. Combs, C. C. 2016. Terrorism in the Twenty - First Century. Seventh edition. New York: Routledge.

Duchemann, A. 2013. Defining terrorism in International Law so as to Foster the Protection of Human Rights, Revue Juridique de l'Océan Indian, 16, pp. 175-211. Available at: http://www.lexoi.fr/index.php?id=5518 (18. 12. 2020).

Jenkins, B. M. 1981. The Study of Terrorism: Definitional Problem. In: Alexander, Y. \& Gleason, J. M. (eds), Behavioural and Quantitative Perspectives on Terrorism. New York: Pergamon Press, pp. 3-10.

Jazić, A. \& Batrićević, A. 2016. Terorizam - politikološki i pravni aspekti. Strani pravni život, 60 (1), pp. 167-184.

Matić Bošković, M. 2016. EU politika borbe protiv terorizma i uticaj na vladavinu prava. Strani pravni život, 60 (2), pp. 103-112.

Milbank, D. L. 1976. Research Study: International and Transnational Terrorism. Washington, DC: CIA Political Research Dept.

Petrović, D. 2007. Moderni koncept terorizma, krivičnopravni aspekt. Kragujevac: Pravni fakultet Univerziteta u Kragujevcu.

Petrović, D. 2009. Samoubilački terorizam. Strani pravni život, 2009, 53(3), pp. 67-108.

Petrović, D. 2014. Pokušaj određenja univerzalno prihvatljive definicije terorizma. Bezbednost, 56(1), pp. 23-40. 
Petrović, D. 2015. Neslaganje oko smisla i suštine terorizma: politički, moralni i verski aspekt. In: Ćirić, J., Džomić, V. \& Jevtić, M. (eds.), Religija - politika - pravo, pp. 645-660. Beograd: Institut za uporedno pravo, Mitropolija Crnogorsko-primorska, Centar za proučavanje religije i versku toleranciju.

Scharf, M. P. 2001. Defining Terrorism by Reference to the Laws of War: Problems and Prospects. In: Countering terrorism through international cooperation: Proceedings of the international conference on "Countering terrorism through enhanced international cooperation", Courmayeur Mont Blanc, Italy, 22-24 September 2000. Milan: ISPAC.

Schmid, A. 2004. Terrorism - The Definitional Problem. Case Western Reserve Journal of International Law, 36 (2-3), pp. 375-381. Available at: https://core.ac.uk/download/ pdf/214078705.pdf, (18. 11.2020).

Walker, C. 2002. Blackstone's Guide to the Antiterrorism Legislation. Oxford: Oxford University Press.

Wilkinson, P. 2004. Political Terrorism. London: Macmillian.

Whittaker, D. J. 2003. The Terrorism reader. 2nd edition. New York: Routledge.

Zirojević Fatić, M. 2014. Terorizam - medunarodni pogled. Beograd: Institut za međunarodnu politiku i privredu.

\section{Website references}

Kelkar, K. 2017. When it comes to defining 'terrorism,' there is no consensus. Nation, Feb. 26. Available at: https://www.pbs.org/newshour/nation/defining-terrorism-consensus (20.11.2020).

Pinjo, E. 2015. Islamski terorizam. Available at: http.www.mm.cp.ba/printart123.html, (14. 12. 2015).

Stuurman, Z. 2019. Terrorism as Controversy: The Shifting Definition of Terrorism in State Politics. Student essay. Sep 24, 2019. Available at: https://www.e-ir.info/2019/09/24/ terrorism-as-controversy-the-shifting-definition-of-terrorism-in-state-politics/, (20.11.2020). 


\title{
Dr Dragana B. Petrović
}

Naučni saradnik, Institut za uporedno pravo, Beograd, Srbija

e-mail:d.petrovic@iup.rs

\section{OPŠTE KARAKTERISTIKE OSNOVNOG POJMA TERORIZMA}

\author{
Sažetak
}

Definisanje nečeg predstavlja uvod u nešto ili u idealnom slučaju, davanje preciznog objašnjenja šta nešto znači - proces koji omogućava da se sagleda razlog i smisao određene pojave, pronikne u njenu suštinu. Međutim, ukoliko se ne može postići preciznost takve vrste, onda se mora ocrtati put ka njenom širem utemeljenju. Na planu konkretne analize, osnovna i polazna analitička kategorija podrazumeva razumno značenje termina „terorizam“, pri čemu se posebno razmatraju njegovi mnogostruko raznovrsni aspekti kao što su motivacija, geografski konteksti, aspekti udruživanja terorista ili njihovo individualno delovanje, buduće forme terorističkog angažovanja. Naravno, tu figuriraju i brojna etička pitanja i problemi, a posebnu pažnju privlači i osvetljavanje „imidža“ koji se o terorizmu kreira kroz medije. Upravo, oni koji nastoje da postignu konsenzus u pogledu značenja termina „terorizam“ $i$ kako se sa njim uhvatiti u koštac, došli su do zaključka da je gotovo nemoguće pronaći okvir za jedinstvenu opšteprihvatljivu definiciju. Međutim, iako ne postoji konsenzus u definisanju terorizma, postoji opšteprihvaćeno shvatanje da teroristi danas deluju globalno i da eskaliraju svoje aktivnost proizvodeći ekstremni haos i nasilje.

Za razmatranje pojmovnog određenja ili definisanja „terorizma“, ovi fragmenti ili izloženi stavovi će nam poslužiti kao upozorenje da se krećemo po veoma „klizavom terenu", gde se neprekidno sudara veliki broj definicija, bogatstvo određenja sa brojnim neusaglašenostima, protivrečnostima, nepreciznostima, nedorečenostima. Neke od definicija su kratke i precizne sadržine, neke samo implicitno kažu sta je „terorizam“, neki koncepti se poklapaju sa onima na kojima počiva sadržaj osnovnog pojma, neke formulacije se baziraju na sasvim suprotnim pristupima u omeđavanju ovog krivičnog dela na oblast nacionalnog zakonodavstva itd. Na kraju, kada se sve svede na jednu ravan, proizilazi da se kao sada nikada nije raspravljalo o ovoj kompleksnoj temi, a da su rezultati do kojih se došlo veoma skromni, čak nezadovoljavajući. Jednom reči, mora se priznati da u tom pogledu i nije ostvaren neki napredak. Pa ipak, individualna i kolektivna naučna misao je na svoj način doprinela definisanju pravnih obrisa terorizma, i najzad njegova obeležja su u značajnoj meri izložena ili određena posebnim ugovorima i precedentnim pravom, za koje se može reći da su ipak kristalizovala ovaj pojam ili njegova osnovna obeležja, tj. glavne karakteristike. Iz ovog upućivanja, kako ističe autor, izvesno je da među mnogobrojnim teorijskim pozicijama postoje znatne razlike. Upravo, kaže on, pogled na ravan suštinskog omeđavanja pojma terorizma omogućiće nam da u sveukupnom pristupu (uz određenu selekciju) dobijemo zanimljive i aplikativne zaključke koji nam, dalje, mogu koristiti u objašnjavanju i proučavanju kako karaktera, tako i specifičnog sadržaja pojma terorizma, a sve u funkciji iznalaženja najoptimalnijeg modela borbe protiv njega, odnosno 
pronalaženja načina pomoću kojih ovaj cilj može da se ostvari. I to uvek iznova, istražujući tu permanentnu društveno-negativnu dimenziju ljudskog ponašanja, ukazujući uvek na nove i nove međusobne veze $\mathrm{u}$ kretanjima i modalitetima njenog manifestovanja.

Ovo treba potcrtati, jer daleko više od drugačijih načina vršenja krivičnih dela, terorizam intenzivira opasnost pri određenim uslovima. Posmatran kroz prizmu društvene stvarnosti, on je životna činjenica, sve češća i sve monstruoznija u ispoljavanju kriminaliteta sa svojom osobenom pojedinačnom i kolektivnom štetnošću, pa stoga i posebna kategorija u krivično-pravnom smislu koja nužno mora da ima i svoje specifičnosti, zaključuje autor. U našem zakonodavstvu ovo krivično delo se tretira članom $391 \mathrm{KZS.}$

Ključne reči: koncept terora, definicija terorizma, razlika između teroriste i borca za slobodu.

Article history:

Received: 23 November 2020

Revised: 4 January 2021

Accepted: 20 January 2021 